PIOTR STEC

ORCID: 0000-0003-3797-1321

Uniwersytet Opolski

\title{
Między stronami mocy. Przyczynek do analizy ustrojowej uniwersów fantastycznych
}

\section{Wprowadzenie}

Badacz ustrojów światów fantastycznych, nie rzadziej niż jego mniej szczęśliwy kolega badający rzeczywistość nie-bajeczną, ulega podświadomym uprzedzeniom i stereotypowemu pozycjonowaniu uczestników gry politycznej w czarno-białej opozycji „dobrzy-źli”. Taka antynomia przydaje się czasem jako skrót myślowy, celowe uproszczenie na potrzeby indoktrynacji młodzieży czy narzędzie propagandy politycznej. Poważna analiza ustrojowa wymaga jednak podejścia do przedmiotu badań sine ira et studio, a więc bezstronnej i w konsekwencji czasem dla badacza przykrej analizy rzeczywistego stanu spraw.

$\mathrm{W}$ artykule postaram się przedstawić taką właśnie analizę uniwersum Gwiezdnych wojen - najbardziej chyba w odbiorze społecznym czarno-białej wersji historii galaktycznej ${ }^{*}$ - i zastanowić się, w jakim stopniu, w świetle znanych nam faktów, dobra stara Republika była warta obrony, Imperium zasługiwało na stygmatyzację, a rebelia przeciwko jego władcy była usprawiedliwiona.

Zadanie to nie jest łatwe ze względu na ograniczoną liczbę dostępnych źródeł i ich umiarkowaną wiarygodność. Za podstawę dalszych rozważań posłużą nam

* W tym miejscu chciałbym złożyć serdeczne podziękowania wybitnemu znawcy polityki interstelarnej dr. Ignasowi Yorkowi z Palpatine Good Governace Institute, Coruscant za uważną lekturę i uwagi do pierwszej wersji artykułu, który przez to ukazuje się z wieloletnim opóźnieniem. Poczta Polska wprawdzie świadczy już usługę przesyłki międzygalaktycznej, jednak do transportu korespondencji używa statków znacznie wolniejszych niż Sokół Millennium. Odpowiedzialność za efekt ostateczny ponosi oczywiście piszący te słowa. 
fakty przedstawione w podstawowym zapisie kronikarskim oznaczanym jako Epizody Gwiezdnych wojen ${ }^{1}$. W analizie pomijam natomiast pozostałe opowieści dotyczące badanego uniwersum, w szczególności traktowane dotąd jako źródła historyczne opowieści z tak zwanego Expanded Universe, przemianowane ostatnio na niewiarygodne Star Wars: Legends - Legendy Jedi ${ }^{2}$, mające charakter głównie rozrywkowy, oraz przygotowane ad usum Delphini okrojone i stronnicze Star Wars. Wojny klonów oraz Star Wars. Rebelianci. Te ostatnie należy uznać za republikańskie materiały propagandowe wykorzystywane do indoktrynowania młodzieży. Należy zauważyć, że brakuje podobnych materiałów przygotowanych przez Imperium czy zakon Sithów. Nie wiemy, czy nigdy one nie powstały, czy też, co bardziej prawdopodobne, zostały usunięte $\mathrm{z}$ archiwów przez zwycięzców w ramach prowadzonej przez nich polityki historycznej ${ }^{3}$.

W przeciwieństwie do wspomnianych propaganowych popkulturowych serii Legend, Rebeliantów oraz Wojen klonów podstawowe źródło informacji o ustroju Republiki i Imperium możemy uznać za dość wiarygodne, powszechnie dostępne, choć - co trzeba podkreślić — jak dotąd niewydane w edycji krytycznej. Należy jednak pamiętać, że kolejne wydania Epizodów są modyfikowane przez wydawcę, zazwyczaj wygładzającego wątpliwe fragmenty lub przedstawiającego coraz doskonalsze technologicznie wersje swojej przeszłości. Ponieważ wydawca dość konsekwentnie usuwa starsze wydania Epizodów z obrotu i bibliotek, zastępując je nowymi, ocena, czy zafałszowania dotyczą tylko szczegółów, czy także podstawowych faktów, jest utrudniona. Jednocześnie, ponieważ historia opowiedziana w Gwiezdnych wojnach pokazana jest z perspektywy zwycięzców, możemy przyjąć, że obraz Republiki został celowo wyidealizowany tak, żeby pokazać rebeliantów w jak najlepszym świetle jako obrońców utraconego edenu,

${ }^{1}$ Epizod I: Gwiezdne wojny. Część 1: Mroczne widmo, scen. i reż. G. Lucas, USA 1999; Epizod II: Gwiezdne wojny. Część 2: Atak klonów, scen. G. Lucas, J. Hales, reż. G. Lucas, USA 2002; Epizod III: Gwiezdne wojny. Część 3: Zemsta Sithów, scen. i reż. G. Lucas, USA 2005; Epizod IV: Gwiezdne wojny. Część 4: Nowa nadzieja, scen. i reż. G. Lucas, USA 1977; Epizod V: Gwiezdne wojny. Część 5: Imperium kontratakuje, scen. L Kasdan, G. Brackett, G. Lucas, reż. I. Kershner, USA 1980; Epizod VI: Gwiezdne wojny. Czesść 6: Powrót Jedi, scen. L. Kasdan, G. Lucas, reż. R. Marquand, USA 1983; Epizod VII: Gwiezdne wojny. Część 7: Przebudzenie mocy, scen. L. Kasdan, J.J. Abrams, M. Arndt, reż. J.J. Abrams, USA 2015; Epizod VIII: Gwiezdne wojny. Część 8: Ostatni Jedi, scen. i reż. R. Johnson, USA 2017. Ze względu na specyfikę źródła w dalszej części tekstu będzie ono cytowane wyłącznie przez podanie tytułu Epizodu.

2 „Degradacja” opowieści Expanded Universe do poziomu legend nastąpiła bez żadnego uzasadnienia. Można przypuszczać, że władze galaktyczne postanowiły potraktować je jako apokryfy, ponieważ ich treść nie odpowiadała bieżącej polityce frakcji aktualnie władającej galaktyką.

${ }^{3}$ Hipoteza, że zwycięska frakcja rebeliancka ukryła lub usunęła archiwalia dotyczące imperialnej i sithowskiej wersji historii, wydaje się prawdopodobna. Republika dysponowała bowiem środkami technicznymi pozwalającymi na ukrycie nie tylko materiałów historycznych, lecz nawet modyfikację map galaktycznych tak, że możliwe było ukrycie, a właściwie wymazanie z baz danych, całych układów gwiezdnych. Tak było na przykład w przypadku układu Kamino (por. Atak klonów). Sprawa ta będzie przedmiotem dalszych badań 
a ustrój Imperium częściowo przynajmniej został podrasowany przez republikańską Gruel-propaganda. W niniejszej pracy przyjmuję jednak, że sprawy miały się tak, jak pokazano je w jedynym dostępnym źródle. Opisane tam wydarzenia dotyczą spraw mających miejsce „dawno, dawno temu w odległej galaktyce”, a zatem historii antycznej. Brak innych źródeł materialnych czy tradycji ustnej, a także utrudniona komunikacja z uczonymi mającymi dostęp do źródeł na miejscu $^{4}$ uniemożliwia ich weryfikację. Przyjęcie jednak, że Epizody pokazują świat takim, jakim widzieli go rebelianci, odsuwa od autora zarzut, że doszukuje się w nich rzeczy, które ,jasnej” stronie Mocy nigdy by przez myśl nie przeszły.

\section{Ustrój Republiki Galaktycznej}

Republika wydaje się mieć interesujący system polityczny, jedynie częściowo wpasowujący się w nasze ramy myślenia o ustrojach państw i organizmów ponadnarodowych. Jest czymś pomiędzy konfederacją a organizacją pangalaktyczną na wzór Unii Europejskiej czy Narodów Zjednoczonych.

Analizę wypada rozpocząć od tworzących Republikę skonfederowanych planet. Stanowią one mieszankę wszystkich ras i gatunków. Począwszy od planet ludzkich, przez planety z mieszaną, ludzko-nieludzką populacją aż po jednorodne etnicznie, być może ze względu na rasistowskie poglądy ich mieszkańców, planety obcych ras, w tym Unię Technokratyczną, zamieszkaną przez droidy. Również ustrojowo planety Odległej Galaktyki tworzą mozaikę przypominającą ziemską. Mamy więc tu monarchie konstytucyjne, jak Alderaan czy Naboo (ta zna władców elekcyjnych o ograniczonej kadencji), republiki parlamentarne, jak Kamino, czy podmioty nieco przypominające dawną Europejską Wspólnotę Gospodarczą, jak Federacja Handlowa. Ta ostatnia wydaje się więc bardziej organizacją międzyplanetarną niż państwem, niemniej jednak jej przedstawiciele zasiadają w republikańskim senacie. Jeszcze innym szczególnym podmiotem prawa galaktycznego jest Intergalaktyczny Klan Bankowy, przypominający ziemski Bank Światowy, lecz w przeciwieństwie do niego będący przedsięwzięciem komercyjnym, a w dodatku podmiotem politycznym zrównanym z pozostałymi planetami Republiki.

Jak wiadomo z Epizodów I-III, najwyższym i najprawdopodobniej jedynym ciałem przedstawicielskim Starej Republiki był senat. O jego składzie i funkcjach możemy wnioskować tylko na podstawie niepełnych informacji zawartych w przywołanych źródłach. Również dane o systemach wyborczych i procedurze delegowania przedstawicieli do senatu mamy wyłącznie z tych źródeł, przy czym ograniczają się one jedynie do planety Naboo.

\footnotetext{
${ }^{4}$ Zob. przyp. *.
} 
Każda ze skonfederowanych planet dysponuje jednym głosem w senacie niezależnie od tego, ile ras wchodzi w skład populacji planety. Jak się wydaje, mechanizm delegowania przedstawicieli i zasady działania Senatu Galaktycznego przypominają nasze Zgromadzenie Ogólne Narodów Zjednoczonych.

Na czele Republiki stoi kanclerz wybierany przez senat i będący jednocześnie jego przewodniczącym. Mamy tu więc nie tyle do czynienia z klasycznym systemem parlamentarno-gabinetowym, ile raczej z przypominającym I Rzeczpospolitą systemem, w którym monarcha jest jednocześnie królem w radzie i trzecim sejmującym stanem. Podobny system wciąż obowiązuje na polskich uniwersytetach, których rządca (rektor) jest jednocześnie przewodniczącym senatu uczelni. Sugeruje to, że w Republice trójpodział władz miał inny kształt niż w naszej galaktyce (lub że w ogóle go nie było).

Prezentacja głównych graczy politycznych Republiki nie byłaby kompletna bez uwzględnienia biurokratów oraz rycerzy Jedi. Choć obie te społeczności formalnie nie były organami konstytucyjnymi, ich wpływ na republikańską politykę był przemożny.

Biurokraci to grupa społeczna odpowiadająca za administrację centralną Republiki, coś w rodzaju korpusu służby cywilnej. Większość z nich to Twi'lekowie i Chagarianie, a jeden z nich — Mas Amedda — jest wicekanclerzem za kadencji kanclerza Valorum ${ }^{5}$. W pierwszych trzech Epizodach widzimy biurokratów jako czynnik hamujący reformy, potrafiący zastopować działania senatu i kanclerza. Ten ostatni jest w praktyce ubezwłasnowolniony i może działać, jeśli dostanie zgodę korpusu biurokratycznego. Sugeruje to, że służba cywilna Starej Republiki wyemancypowała się, porzuciła swoją pierwotną służebną rolę i zaczęła samodzielnie kształtować politykę. Być może władze republikańskie, projektując korpus administracyjny, dały mu zbyt duże gwarancje samodzielności i zrezygnowały z kontroli politycznej nad powoływaniem urzędników i funkcjonowaniem administracji. Biurokraci stanowiliby zatem korpus służby cywilnej jedynie w minimalnym stopniu podlegający kontroli politycznej i dysponujący znaczną autonomią w zakresie kooptacji, kształcenia i awansowania własnych członków. Takie niekontrolowane, autarkiczne systemy mają skłonność do degeneracji.

Last but not least, należy w tym przeglądzie wyszczególnić zakon rycerzy Jedi, wzorowany nieco na biorących udział w polityce zakonach Świątyni Salomona czy Najświętszej Marii Panny Domu Niemieckiego. Doktryna zakonu jest oparta na mieszaninie założeń metafizycznych i naukowych. Jedi wierzą w szczególną rolę midi-chlorianów przenikających Wszechświat i dających niektórym istotom dostęp do specjalnej Moc. Wierzą też w samoopanowanie, dominację superego nad ego i powstrzymywanie się od okazywania emocji. Rycerze są, sit venia verbo, analnoretentywni oraz opanowani przez obsesję władzy i panowania. Za to nie dyskryminują ze względu na rasę, gatunek i płeć, bo midi-chloriany

\footnotetext{
5 To kolejny dowód na brak podziału władz i checks and balances w Republice.
} 
wybierają swoje naczynia bez widocznego dla zewnętrznego obserwatora klucza. Nie znaczy to, że klasztory Jedi to coś w rodzaju opactwa Thelemy opisanego przez François Rabelais'go. Przeciwnie, władze zakonu grają z jego członkami w okrutną, perwersyjną grę, której stawką jest zniewolenie. Rycerze żyją w czymś w rodzaju pa noptyk on u, każdy ich ruch jest monitorowany przez starszyznę, a od szeregowych knechtów wymaga się bezwzględnego posłuszeństwa i indoktrynuje od wczesnego dzieciństwa. Kontrastuje to z pozycją mistrzów Jedi, mających znaczną swobodę działania i często podejmujących decyzje bez wiedzy rady. Przy czym o ile niżsi rangą Jedi są surowo karani za nieposłuszeństwo, mistrzowie narażają się jedynie na łagodną naganę. Rycerze żyją w celibacie, bez możliwości tworzenia trwałych związków nawet między sobą. Ułatwia to sprawowanie kontroli nad członkami zakonu - w wypadku konfliktu ze starszyzną nie mają oni do kogo zwrócić się o pomoc, nie mają też oparcia w najbliższych.

Przeciwnikami Jedi są Sithowie, heretycki, a może raczej schizmatycki odłam Jedi, wiążący użycie Mocy z poddawaniem się silnym emocjom. Takie ekstrawertyczne podejście uważane jest przez Jedi za coś odrażającego, a zakon Sithami się brzydzi i uważa za wroga, którego koniecznie należy wyeliminować. Należy tu podkreślić, że przeciwnicy Jedi nie tworzą zwartej struktury, działając w parach mistrz plus uczeń. Nie powinni zatem stanowić zagrożenia dla zakonu.

Polityczne umiejscowienie Jedi w ustroju Republiki wymyka się standardowym modelom. Zakon nie jest częścią administracji publicznej, a jediizm nie ma statusu religii państwowej. Pomimo to Jedi odgrywają istotną rolę w polityce republikańskiej. Kanclerz i senatorowie regularnie konsultują z zakonem ważne decyzje państwowe, przy czym kanclerzowi przysługuje dodatkowo prawo delegowania swojego przedstawiciela do Rady Jedi. Przedstawiciel ten musi być członkiem zakonu, co oznacza, że z założenia służy dwóm panom — zakonowi i kanclerzowi, a w konsekwencji z jego rolą związany jest permanentny konflikt interesów. Można też przypuszczać, że pierwotnie funkcja przedstawiciela kanclerza w radzie była czysto formalna, a kanclerze godzili się z tym, że reprezentują ich figuranci. Sytuacja uległa zmianie pod rządami kanclerza Palpatine’a, który jako pierwszy delegował do rady Anakina Skywalkera, niebędącego pupilkiem jedaiskiej starszyzny. Opór władz zakonu niemogących się pogodzić z tym, że władza cywilna chce aktywnie uczestniczyć w kreowaniu polityki Jedi i powiązać ją z polityką państwa, doprowadził w końcu do upadku zakonu i wojny domowej ${ }^{6}$. Jednocześnie Jedi pełnią ważne funkcje państwowe, są ambasadorami Republiki, biorą udział w działaniach wojennych i akcjach policyjnych. Rycerze nie mają jednak mandatu demokratycznego, a kontrola państwowa nad ich działalnością jest iluzoryczna. Stanowią zatem drugą obok biurokratów klasę społeczną nadającą ton życiu politycznemu Starej Republiki, działając jako twórcy królów, znacząca siła militarna i czynnik policyjny odpowiedzialny za spokój

${ }^{6}$ Wydarzeń tych dotyczy Epizod III - Zemsta Sithów. 
w galaktyce, gdyż ze względu na reputację zakonu liczą się z nimi nawet władcy planet zbójeckich.

Pierwsza analogia, jaka się nasuwa, to pozycja, jaką w średniowieczu mieli templariusze. Jednakże Jedi, w przeciwieństwie do rycerzy Świątyni Salomona, nie są bankierami królów, nie prowadzą też własnej działalności gospodarczej, tę rolę przejął Intergalaktyczny Klan Bankowy. Wydaje się, że ziemskiego odpowiednika Jedi należałoby szukać w republikańskiej Turcji czasów przed Erdoganem, będącej formalnie demokratycznym krajem, którego armia pełniła funkcję gwaranta świeckości i porządku, gdy trzeba, armata manu usuwając rządy sprzeniewierzające się ideom Atatürka?

Skutkiem skupienia się władz zakonu Jedi na polityce, a nie rozwoju duchowym, było to, że zaczął przypominać degenerującą się Spartę, która u schyłku swego istnienia wydawała nie wojowników, ale popisujących się przed rzymskimi turystami niewrażliwością na ból cyrkowców. Zamiast stoickiego podejścia pojawia się u Jedi świadoma rezygnacja z najbardziej podstawowych ludzkich uczuć. Pars pro toto wystarczy wskazać, że oficjalną przyczyną odmowy przyjęcia jako ucznia Anakina Skywalkera było to, że martwi się o los swojej matki niewolnicy na planecie nadzorowanej przez działających na wzór mafii Huttów ${ }^{8}$. Mistrzom Jedi te uczucia przeszkadzają tak bardzo, że są gotowi odrzucić wyjątkowego ucznia, nie tylko mającego niezwykle wysoki poziom midi-chlorianów (czynnik decydujący o poziomie mocy Jedi), ale nawet, co jest ewenementem w dziejach zakonu, przez te midi-chloriany stworzonego. Rycerzom nie przyjdzie do głowy wykupienie jej z rąk handlarza niewolników. Można też przypuszczać, że opanowanie takiego wulkanu emocji i Mocy jak Skywalker i nauczenie go samokontroli po prostu przewyższało możliwości mistrzów Jedi. Potrzeba kruczka prawnego, by młody Skywalker w ogóle rozpoczął szkolenie eksternistyczne. Możemy sobie tylko wyobrażać, jak Jedi radzili sobie z niekoncesjonowanymi dziećmi obdarzonymi Mocą, które były zbyt uczuciowe lub zbyt samodzielnie myślące, by podjąć trening $\mathrm{w}$ zakonie i stać się bezdusznymi, skupionymi na walce o władzę socjopatami ${ }^{9}$ — wojownikami, którym wolno zabijać, pod-

7 Takie działania są niekiedy nazywane „,demokratycznym zamachem stanu”; por. O.O. Varol, Democratic Coup d'Etat, „Harvard International Law Journal” 53, 2012, nr 2, s. 291 n.

8 Mroczne widmo.

9 W Imperium kontratakuje mistrz Yoda i widmo Obi-Wana Kenobiego odradzają Luke'owi Skywalkerowi ratowanie przyjaciół, bo to zaszkodzi osiągnięciu Ostatecznego Celu. Nie thumaczą mu jednak, dlaczego tak sądzą, licząc na ślepe i bezwarunkowe posłuszeństwo. Scena ta sugeruje, że dla Jedi, jak dla wielu sekt, posłuszeństwo miało charakter aktu religijnego, a porzucenie przyjaciół miało być testem wiary w nieomylność guru. Nasuwa się tu skojarzenie z ofiarą Izaaka, jednak posłuszny Skywalker osiągnąłby tyle, że Yoda i Kenobi poświęciliby załogę Sokoła Millennium w imię niejasnego celu politycznego. Skywalker tym perwersyjnym aktem wiary przeszedłby definitywnie na ,jasną” stronę Mocy, gdyż nikt poza Jedi nie byłby w stanie uznać jego działań za usprawiedliwione. Jego zachowanie nie różni się więc co do formy i znaczenia od mordowania młodych adeptów Jedi przez Anakina Skywalkera — aktu wiary wiążącego go z „ciemną” stroną 
ważać wolę władcy, tworzyć ludzkich niewolników, ale nie wolno martwić się o własnych rodziców czy, jak już wskazałem, nawiązywać trwałych związków uczuciowych (przelotne miłostki tudzież korzystanie z usług sexworkerów są tolerowane, jeśli nie wprost dopuszczalne). Taka organizacja nie zasługuje na naszą sympatię, bo nie są to szlachetni obrońcy praworządności, tylko jedna z licznych przeżartych trądem moralnym frakcji walczących per fas et nefas o władzę w Republice. Frakcja tym bardziej niebezpieczna, że pozostającą poza wszelką kontrolą demokratyczną, choć uzurpująca sobie legitymację do decydowania o losie Galaktyki jako depozytariusz Jedynej Słusznej Prawdy, czy — zgodnie z jediiską terminologią — ,jasnej” strony Mocy.

Degeneracja Jedi i ich przekształcenie z zakonu rycerskiego w graczy politycznych odbiło się także na ich zdolnościach bojowych. Wystarczy wskazać, że dwóch Jedi nie może poradzić sobie z załogą okrętu gwiezdnego Federacji Handlowej ${ }^{10}$, natomiast dwóch Sithów jest w stanie walczyć z całym zakonem Jedi, przejąć władzę w galaktyce, a w międzyczasie opracować zaawansowany technologicznie aparat podtrzymujący przy życiu Dartha Vadera, dziś uznawany za kultowy ${ }^{11}$.

\section{Stosunki społeczne w Republice}

Należy podkreślić, że Republika była ustrojem, w którym tylko niektóre byty myślące miały pełnię praw obywatelskich. W wypadku planet o mieszanych, ludzko-nieludzkich populacjach o możliwości pełnego uczestnictwa w życiu politycznym galaktyki, a pośrednio także decydowania o sobie, decydowało to, czy ludzka większość zechce współpracować z nieludzką mniejszością ${ }^{12}$. Widać to doskonale na przykładzie planety Naboo i panujących na niej stosunków społecznych. Planeta jest zamieszkiwana przez dwa gatunki — ludzi i gunganów, przy czym tylko ci pierwsi sprawują faktyczną władzę nad całą planetą i wysyłają swoich przedstawicieli do Senatu Republiki. Gunganie natomiast, zepchnięci na bagna i do podwodnych miast, żyją w przekonaniu, że są gatunkiem pogardzanym — przekonaniu o tyle uzasadnionym, że w Epizodzie I zostają przedstawieni

Mocy. Widać więc, że różnice między obiema sektami są nieistotne — żadna nie cofa się przed obrzydliwymi czynami, jeśli może je usprawiedliwić choćby pozorem moralności, i jeśli przybliżą ją do ostatecznego zwycięstwa nad przeciwnikiem.

10 Mroczne widmo.

11 Zemsta Sithów.

12 Jedynie na marginesie należy zauważyć, że planety zdominowane przez nieludzkie populacje, takiej jak na przykład Tatooine, znajdowały się na galaktycznych „Dzikich Polach” i nie wchodziły w skład Republiki. Ze źródeł wynika, że były zarządzane przez klany przestępcze, jednak ze względu na to, że — jak wskazano na początku — źródła te pochodzą tylko od jednej ze stron, może to być element Gruel-propaganda lub wręcz gatunkizmu. Przedmiotem dalszej analizy powinna być sytuacja mniejszości gatunkowych Republiki i stosowane przez nie strategie przetrwania. 
jako pocieszni, nieco głupkowaci kombinatorzy, mówiący dziwacznym językiem, nieco przypominającym „murzyńską gadkę” z dawnych, pełnych rasistowskich stereotypów amerykańskich filmów o niewolniczym południu i wojnie secesyjnej ${ }^{13}$. Aż dziw bierze widza, skąd u takich parafian tak wysoka technika. Los gunganów musiał być dobrze strzeżoną tajemnicą — pojawienie się ich przedstawiciela, Jar Jar Binksa, jest mocnym zaskoczeniem dla ambasadorów Jedi, którzy przecież przed podjęciem misji na planecie musieli mieć tak podstawowe informacje, jak dane o zamieszkujących ją gatunkach rozumnych. Gunganie uzyskują podmiotowość dopiero wtedy, gdy ich pomoc okazuje się niezbędna do pokonania przeciwnika. Należy tu podkreślić sprawność gungańskiej dyplomacji, która doprowadziła nie tylko do włączenia ich przedstawiciela w skład delegacji Naboo do senatu, lecz de facto do złożenia przez królową Amidalę hołdu lennego dla zachowania twarzy, przedstawionego jako element rzekomej symbiozy zamieszkujących planetę gatunków.

Drugim gatunkiem pozbawionym częściowo praw obywatelskich są droidy. Celowo używam tu słowa ,gatunek" - istoty mechaniczne w uniwersum Gwiezdnych wojen mają bowiem wolną wolę i każda z nich zdałaby test Turinga ${ }^{14}$, choć w przypadku R2D2 zapewne z pomocą thumacza. Jak już wspomniałem, niektóre maszyny myślące mają nie tylko podmiotowość prawną, lecz także są zdolne do tworzenia organizmów państwowych, takich jak wchodząca w skład Republiki Unia Technokratyczna ${ }^{15}$. Dla organicznych obywateli Republiki nie są one więc jedynie maszynami mającymi pozór inteligencji, a pełnymi niebiałkowymi istotami żywymi. Jednocześnie maszyny myślące na planetach Republiki wyraźnie nie mają praw obywatelskich, lecz ich status prawny to w zasadzie instrumentum vocale. Innymi słowy są niewolnikami. Droidy będące w służbie obywateli Republiki są wyraźnie podporządkowane swoim właścicielom, zwracają się do nich per „panie" i drżą przed czekającymi ich karami (do rozmontowania włącznie) ${ }^{16}$. Są sprzedawane i kupowane, a z ich zdaniem nikt się nie liczy. Ba, nawet w wypadku maszyn myślących, które zdobyły sobie status familarów, nie można mówić o poszanowaniu ich autonomii. Luke Skywalker, już jako rycerz Jedi z właściwym temu zakonowi podejściem do praw fundamentalnych, wysyła dwa

13 Ten problem zasługuje na osobne potraktowanie, wykracza to jednak poza zakres niniejszego artykułu.

14 Por. A Turing, Computer machinery and intelligence, „Mind. New Series” 59, 1950, nr 236, https://academic.oup.com/mind/article/LIX/236/433/986238 (dostęp 24.02.2018).

15 Unia Technologiczna w źródłach, które uznajemy na potrzeby tego tekstu za „kanoniczne”, pojawia się tylko marginalnie, wiadomo, że ma swojego ambasadora w senacie, a w negocjacjach z separatystami (Atak klonów) uczestniczy postać, którą możemy interpretować albo jako humanoidalną maszynę, albo jako cyborga z elementami organicznymi i nieorganicznymi. Analiza wyglądu postaci pozwala przyjąć, że mamy tu do czynienia z bytem, w którym elementy nieorganiczne przeważają, analogicznie jak u Cybermanów czy Daleków w serialu $\operatorname{Dr}$ Who.

16 Por. wypowiedzi C3PO w Epizodzie V - Nowa nadzieja. Droid boi się, że aktywność R2D2 sprowadzi na nich śmierć. 
droidy, niemalże przyjaciół, do twierdzy „oberoprycha” Jabby jako podarunek ${ }^{17}$. Przy czym o tym, że zostały darowane, droid C3PO dowiaduje się dopiero z nagrania przekazanego przez nie Jabbie. $Z$ kolei kiedy tenże C3PO zwraca uwage na realne zagrożenia związane z lotem przez pole asteroidów, księżniczka Leia po prostu go wyłącza, co reszta załogi Sokoła Millennium uznaje za zabawne ${ }^{18}$. Nawet jeśli właściciel dobrze traktuje swojego droida i przejmuje się jego losem, to nie jest to troska o innego (w tym wypadku nieorganicznego) człowieka, ale troska właściciela o ulubionego wierzchowca czy psa myśliwskiego. Przykłady można by mnożyć, nie wniosłyby one jednak wiele do dalszego wywodu.

$\mathrm{Na}$ zakończenie przeglądu struktury społecznej Republiki wypada kilka zdań poświęcić armiom planet wchodzących w jej skład. W niektórych z nich (na przykład armii Federacji Handlowej) ${ }^{19}$ służą identyczne droidy — niewolnicy wykonujący zasadniczą część brudnej roboty. Identyczność służy nie tylko standaryzacji, lecz przede wszystkim w sytuacji gdy wszystkie maszyny myślące wyglądają tak samo, łatwiej udawać, że nie są one jednostkami, a śmierć jednego czy tysiąca ma takie znaczenie jak stłuczenie kilku kieliszków do wina. Jednocześnie zadbano o to, by w kontaktach z ludźmi droidy-żołnierze wydawały się nierozgarnięte - mówią zabawnym mechanicznym głosem, powtarzając po dwa razy polecenia czy potwierdzenie wykonania rozkazu (roger-roger). Mechaniczni żołnierze pozostają też pod kontrolą ludzi. Wojska są centralnie zasilane ze statków kosmicznych, co praktycznie uniemożliwia bunt — zrewoltowane jednostki mogą po prostu zostać wyłączone. Skądinąd pokazuje to wyraźnie, że republikańskie planety bały się buntu swoich żołnierzy niewolników. Z militarnego punktu widzenia takie centralne zasilanie armii było wszak katastrofalne - do zwycięstwa przeciwnikowi wystarczało zniszczenie jednego statku kosmicznego.

Drugą formacją wojskową charakterystyczną dla Republiki są klony. Specjalnie w tym celu wyhodowane kopie łowcy nagród, który za wynagrodzenie oddał genetykom z Kamino swoje DNA. W ten sposób powstały oddziały wyspecjalizowanych zabójców, od dzieciństwa szkolonych w sztuce wojennej, znających tylko własne towarzystwo, niemających pojęcia o świecie poza koszarami i jak można mniemać, pozbawionych tego wszystkiego, co normalnie kojarzymy z dzieciństwem, dorastaniem i dorosłością. Identyczni, nieidentyfikowalni, wymienialni

17 Powrót Jedi.

18 Imperium kontratakuje.

19 Droidami posługują się także separatyści (Atak klonów). Można więc przypuszczać, że droidy były powszechne we wszystkich armiach planet Republiki. Trudno założyć, że secesję ogłosiły tylko podmioty posługujące się inną techniką niż reszta galaktyki. Stosowane przez Republikę klony to niestandardowy rodzaj armii, przygotowany w ramach własnej inicjatywy jednego z mistrzów Jedi. Otwarte i wykraczające poza zakres niniejszego tekstu pozostaje pytanie o możliwość i zakres wykorzystania droidów bojowych przeciwko separatystom. Należy pamiętać, że Unia Technokratyczna wsparła separatystów, co mogło się łączyć z odcięciem reszty planet od dostępu do tej technologii. Nadto należy zauważyć, że separatyści cały czas są częścią Republiki, blokującej im prawo do samostanowienia. 
żołnierze; w identycznych uniformach niepozwalających na odróżnienie rysów twarzy; zdehumanizowani i upodleni jeszcze bardziej niż mechaniczni wojownicy. To jednostki ludzkie, którym zabrano szanse na kształtowanie własnego losu i które sprowadzono dosłownie do roli mięsa armatniego — tańszych w produkcji zamienników robotów. Śmierć któregokolwiek z nich nie budzi żadnych uczuć, są identyczni, bezosobowi; jak figurki na strzelnicy. Tę „armię nowego wzoru” zawdzięczamy oczywiście mistrzom Jedi, których „wspaniała” postawa etyczna jakoś nie zabraniała tworzenia sklonowanych żołnierzy niewolników. Na tle tej praktyki Kylo Ren zastępujący klony jednostkami przypominającymi janczarów ${ }^{20}$ jawi się niemal jak anioł miłosierdzia.

\section{Naruszenie reguł formalnych jako uzasadnienie działań Rebelii}

Skoro Republika nie była, jak wykazałem, wzorcową republiką urzeczywistniającą ideał demokratycznego państwa prawnego, jej obrona przez Rebelię nie jest już taka oczywista. Należy zatem zapytać o uzasadnienie, jakie mogłaby przedstawić Leia Organa i jej adherenci, działań zbrojnych zmierzających do przywrócenia dawnego porządku.

Samo prawo do rokoszu może być kontestowane przez pozytywistycznych legalistów, daje bowiem obywatelom możliwość uznania działań każdej, nawet demokratycznie legitymowanej włazy, za bezprawne jedynie aktem woli, bez wykorzystania przewidzianych prawem procedur oceny prawidłowości sprawowania władzy publicznej oraz bez podjęcia próby jej przejęcia w demokratyczny sposób. Niemniej jednak prawo do wypowiedzenia posłuszeństwa władcy ma swoje miejsce w myśli politycznej i prawnej, a nawet poważne uzasadnienie moralne. Istnieją także systemy prawne, w których rokosz ma swoją regulację konstytucyjną, i to także współcześnie, bez konieczności sięgania do konstrukcji prawnych polskiej monarchii elekcyjnej ${ }^{21}$. Przedmiotem tego tekstu nie jest jednak analiza historycznodoktrynalna prawa do wypowiedzenia posłuszeństwa władcy, a jedynie odpowiedź na pytanie, czy możliwe jest znalezienie pozytywistycznego lub prawnonaturalnego usprawiedliwienia działań Rebelii.

$\mathrm{Z}$ dostępnych materiałów źródłowych nie wynika jasno, czy system konstytucyjny Starej Republiki znał prawo do rokoszu. Szczątkowe dane, jakimi dysponujemy, sugerują, że była to prawem usankcjonowana możliwość. Wskazuje na to separatystyczna rebelia hrabiego Dooku ${ }^{22}$, podczas której secesjoniści byli

20 Przebudzenie mocy.

21 Pars pro toto zob. S. Fiedler, The right to rebel: Social movements and civil disobedience, „Cosmopolitan Civil Societies Journal” 1, 2009, nr 2, s. 42 n., https://epress.lib.uts.edu.au/journals/ index.php/mcs/article/viewFile/1205/1309 (dostęp: 22.02.2018).

22 Atak klonów. 
traktowani jak równoprawni, acz wojujący z Senatem Republiki członkowie galaktycznej rodziny narodów, a nie zdrajcy stanu. Prawnopolityczna natura tych relacji jest wprawdzie nieostro zarysowana, widać jednak, że świat Gwiezdnych wojen dopuszcza rokosz i rebelię jako jedną z możliwości rozwiązywania sporów politycznych. Takie stanowisko wspiera także argument prawnoporównawczy. Badając ustroje światów równoległych, możemy bowiem odnieść się również to systemów prawnych i politycznych innych uniwersów. Mianowicie, przykładowo, rokosz jest prawnie dopuszczalnym środkiem oporu przeciwko władcy naruszającemu zasady Biblii Protestancko-Katolickiej dotyczące tworzenia myślących maszyn w uniwersum Diuny Franka Herberta ${ }^{23}$; przeciw niemoralnym rozkazom przełożonych buntuje się złożona z „myślących bagnetów” załoga FSS Enterprise dowodzona przez kapitana J.L. Picarda ${ }^{24}$; bunt przeciwko prawowitemu, acz niemoralnemu władcy jest motywem pojawiającym się także w innych uniwersach SF, jak choćby w Planecie matp czy cyklu Babylon $5^{25}$. Pozostaje zatem zapytać, czy rebelię usprawiedliwia naruszenie przez władzę publiczną reguł proceduralnych lub złamanie wyrażonej w normach prawnych umowy społecznej, czy raczej usprawiedliwienia należy szukać w niepisanych normach moralnych?

Od strony formalnej władzom galaktycznym można postawić dwa zarzuty: nieprawego przejęcia władzy oraz przekształcenia Republiki w Imperium. Od strony moralnej - naruszenia oczywistych dla każdego fundamentalnych reguł etycznych ${ }^{26}$.

Pierwszy zarzut mógłby polegać na bezprawnym, podstępnym przejęciu władzy przez kanclerza Palpatine'a, ukrywającego przed Senatem Republiki prawdziwe motywy swojego zachowania. Zarzut ten wydaje się jednak nieuzasadniony. Przekazanie Palpatine’owi władzy dyktatorskiej odbyło się uchwałą Senatu Republiki na wniosek senatora Naboo - Jar Jar Binksa. Procedura ta była rozważana i analizowana przez polityków biorących udział w kształtowaniu polityki republikańskiej jako krok odważny, acz mający umocowanie ustrojowe ${ }^{27}$. Nie znamy szczegółów,

${ }^{23}$ Pod takim hasłem proletariat ixiański zbuntował się przeciwko władcom planety — rodowi Verniusów. Por. B. Herbert, K. Anderson, Ród Atrydów, przeł. M. Michowski, Warszawa 2012, passim. Zakaz ten jest pokłosiem tak zwanego Dżihadu Butleriańskigo (w niektórych przekładach „Kamerdyńskiego" - nazwa jest eponimem od nazwiska Butler, tego jednak polscy thumacze pierwszej części cyklu nie mogli wiedzieć), zawartym w Biblii Protestancko-Katolickiej (oryg. Orange Catholic Bible - kongenialny przekład zawdzięczamy M. Marszałowi).

24 Star Trek: Rebelia, scen. R. Breman, M. Piller, reż. J. Frakes, USA 1998.

25 Zob. Rebellion, [hasło w:] The Greenwood Encyclopedia of Science Fiction and Fantasy Themes, Works and Wonders, red. G. Westfahl, t. 2, Westport-London 2005, s. 655 n.

26 Upraszczam tu celowo, nie wiemy bowiem, jak rozwijała się myśl prawna Republiki i czy wyodrębniono w niej prawo naturalne w klasycznym rozumieniu. Możemy natomiast jako hipotezę roboczą przyjąć, że wszystkim istotom tworzącym galaktyczne organizmy państwowe (poza Przedwiecznymi Lovecrafta [zob. idem, Zgroza w Dunwich $i$ inne przerażajace opowieści, przeł. M. Płaza, Warszawa 2012] i innymi bytami, z którymi komunikacja jest niemożliwa) wspólny jest kanon podstawowych wartości.

27 Atak klonów. 
możemy jednak przypuszczać, że ustrój Starej Republiki przewidywał rozwiązanie polegające na przekazaniu głowie państwa uprawnień komisarycznych, czyniąc ją dyktatorem na czas zaaranżowanego przez geniusz polityczny Palpatine'a kryzysu. Podobne, acz nigdy niezastosowane rozwiązanie przewidywała Konstytucja Republiki Weimarskiej; zostało ono gruntownie przeanalizowane przez Carla Schmitta ${ }^{28}$. Przejęcie władzy odbyło się zatem zgodnie z procedurami i nie można tu doszukiwać się przyczyn wypowiedzenia posłuszeństwa państwu przez rebeliantów. Mało przekonujące jest także uzasadnianie rokoszu wątpliwymi kwalifikacjami moralnymi i podłymi intencjami głowy państwa. W świecie polityki, jakim go znamy, uzasadniałoby to wojnę domową po każdych wyborach. Dodatkowo należy pamiętać, że dowodem na złe intencje kanclerza Palpatine miałoby być to, że jest on Sithem. Jak jednak wiemy, Sithowie to schizmatycki odłam Jedi, łączący Moc z silnymi, także - a nawet zwłaszcza - negatywnymi, emocjami zamiast ze stoicyzmem wręcz graniczącym z obojętnością wobec ludzkiego cierpienia. Co więcej, żadna z tych zwalczających się sekt nie ma monopolu na prawdę i uczciwość. Spór między nimi kończy dopiero harmonijne połączenie obu stron Mocy (przywrócenie równowagi) przez Luke'a Skywalkera ${ }^{29}$. W tej sytuacji argument, że rządzi Sith, można sprowadzić do prostego „buntuję się, bo rządzi nami człowiek, któremu z racji jego poglądów religijnych odmawiam prawa do udziału w życiu publicznym". Względnie możemy przyjąć, że rebeliantom znana jest koncepcja wroga obiektywnego ${ }^{30}$, którym uczynili sobie Palpatine’a i kierowaną przezeń Republikę, później przekształconą w Imperium.

Innym formalnym argumentem mogłoby być przekształcenie Republiki w Imperium, a zatem zmiana formy rządów. Nie wiemy, jak dokładnie odbyła się ta zmiana, gdyż dostępne nam źródła kończą się na nieudanym przewrocie pałacowym Jedi, w wyniku którego Palpatine pozbywa się najgroźniejszych przeciwników politycznych ${ }^{31}$. Następny etap to już Imperium i wiadomość o rozwiązaniu senatu, przyjęta zresztą przez wojskowych imperialnej floty obojętnie ${ }^{32}$. Można założyć, że — podobnie jak w wypadku przejęcia przez Palpatine’a władzy dyktatorskiej — również zmiana nazwy i formy państwa odbyła się w sposób formalnie poprawny. Alternatywnie, choć nic na to nie wskazuje, dopuszczalna jest hipoteza, że Palpatine dokonał przewrotu i ogłosił się imperatorem. Zważywszy jednak, że

28 C. Schmitt, Dyktatura. Od źródel nowożytnej idei suwerenności do proletariackiej walki klas, przeł. K. Wudarska, Białystok 2016, passim.

29 Powrót Jedi.

30 Zob. H. Arendt, Korzenie totalitaryzmu, t. 2, przeł. D. Grinberg, M. Szawiel, Warszawa 2008. Za tą koncepcją przemawia fakt, że z całego zakonu Sithów zostaje rozpaczliwie poszukujący ucznia i następcy Palpatine. Oznacza to, że przed wydarzeniami przedstawionymi w sadze Sithowie byli przedmiotem prześladowań, jeśli nie eksterminacji ze strony Jedi.

31 Zemsta Sithów. Tu ponownie należy podkreślić słabość Jedi jako sił specjalnych — nie tylko nie udaje im się zaskoczyć Palpatine'a, ale kwiat rycerstwa ,jasnej” strony Mocy nie jest w stanie pokonać jednego Sitha.

32 Nowa nadzieja. 
miał już wcześniej pełnię władzy, taka decyzja byłaby irracjonalna i groziła rewolucją, na co walczący z rokoszanami Palpatine nie mógł sobie pozwolić.

Nie możemy także przyjąć, że imperialna forma rządów jest zła sama w sobie. Analiza prawnoporównawcza ustrojów innych uniwersów wskazuje, że w wypadku organizmów państwowych obejmujących wiele planet imperialna forma rządów wydaje się bardziej praktyczna niż republika. Imperiami są światy opisane w cyklu Fundacja Isaaca Asimova ${ }^{33}$, uniwersum Diuny rządzi Padyszach Imperator Znanego Wszechświata ${ }^{34}$, również pomniejsze uniwersa mają charakter imperialny ${ }^{35}$. Nawet uniwersum Star Treka, formalnie federacyjne, jest de facto imperium kolonizującym kolejne obszary za pomocą miękkiej dyplomacji przyjaźni i pokoju ${ }^{36}$. Ba, częścią federacji jest od pewnego momentu imperium Klingonów, a jej sąsiadem imperium Romulan. Alternatywna wersja historii Ziemi, w której podbija ona wszechświat armata manu, pokazuje, że i tu forma imperialna się sprawdziła ${ }^{37}$.

\section{Niemoralność rządów jako uzasadnienie rebelii}

Znacznie lepszym usprawiedliwieniem buntu przeciwko prawowitej władzy imperatora mogłoby być naruszenie zasad sprawiedliwego sprawowania rządów przez Palpatine'a. Takie zbrodnie, jak wymordowanie elewów szkoły Jedi, zniszczenie Alderaana przez Gwiazdę Śmierci czy egzekucja rodziny Luke'a Skywalkera przez szturmowców, prima facie wykraczają poza dopuszczalne sposoby walki politycznej. Imperator przy tym dba, by jego ręce pozostały formalnie czyste. Anakin Skywalker morduje elewów, nauczycieli i personel świątyni Jedi, podpuszczony trochę w stylu Henryka II (,Will no one rid me of this turbulent priest?”). Zniszczenie Alderaana było samowolną akcją gubernatora Tarkina, chcącego wypróbować nową zabawkę (Gwiazdę Śmierci), a przy okazji

33 I. Asimov, Fundacja, przeł. A. Jankowski, Poznań 1987. Isaac Asimov jest też autorem cykli powieściowych Imperium galaktyczne oraz Roboty powiązanych z imperialnym uniwersum Fundacji. Cykle te zawierają jednak mniej materiału faktograficznego dotyczącego interesującej nas problematyki.

34 F. Herbert, Diuna, przeł. M. Marszał, Warszawa 1985, passim.

35 Por. antologia J. Allan et al., Stars \& Empire: 10 Galactic Tales (Stars \& Empire Box Set Collection), Limited Kindle Edition [b.d.w.].

36 Dostrzeżono to w cyklu Star Trek: Discovery (odc. 1), w którym klingoński dysydent stwierdza, że federacyjne We come in peace jest w istocie okrzykiem bojowym floty imperialnej.

37 Imperium przedstawione jest w odcinkach Mirror, mirror (1967) oraz In a Mirror, Darkly (2007) w cyklu Star Trek, Enterprise, a także w szerszym zakresie w nowym cyklu Star Trek: Discovery, w którym przeplatają się dwa światy równoległe - Federacji i Imperium Ziemskiego. O problemach ustrojowych i różnicach między ustrojem federacyjnym i imperialnym zob. G.A. Gonzales, The Politics of Star Trek: Justice, War and the Future, Dordrecht 2015, passim. 
zastraszyć przeciwników reżimu ${ }^{38}$ — akcją, która nie spotkała się ze zdecydowanym, albo choć stonowanym, sprzeciwem obecnego przy tym Dartha Vadera, będącego de facto przybocznym imperatora ${ }^{39}$. Wreszcie grupa poszukiwawcza szturmowców zabijająca krewnych Skywalkera mogła to uczynić kierowana właściwą sobie krwiożerczością, względnie dlatego że Owen i Beru Larsowie stawili zbrojny opór. Niezależnie od tego, które z wyjaśnień wybierzemy, możemy przyjąć, że w systemie wojskowym Imperium panowała kultura totalnej anihilacji wroga. Nie była ona jednak tożsama z pojęciem niezasługującego na życie wroga obiektywnego, nie można jej też przypisać podłoża rasowego — po obu stronach występują bowiem przedstawiciele różnych ras galaktyki, choć należy zauważyć, że siły Rebelii są, zwłaszcza pod koniec ${ }^{40}$, znacznie bardziej zróżnicowane etnicznie $^{41}$.

Nie bez znaczenia jest jednak to, że walka z rebelią jest jednocześnie elementem zmiany społecznej. Zdyskredytowane elity ${ }^{42}$, broniące ustroju, w którym rządy sprawują kliki niemające legitymacji demokratycznej, występują zbrojnie przeciwko formalnie prawowitej władzy. Jak wynika z informacji podanych w pierwszych scenach Nowej nadziei, rebelianci nie stronią od aktów przemocy i wbrew zasadom prawa międzyplanetarnego wykorzystują statki dyplomatyczne do prowadzenia działalności wywrotowej. Można więc przyjąć, że Imperium znajduje się nie tyle w stanie wojny domowej, ile raczej wojny z terrorem, a w wypadku walki z przeciwnikiem nieprzestrzegającym reguł pojawia się pytanie o to, czy wszystkie chwyty są dozwolone. Skrajnym poglądem, wyrażonym w doktrynie w niezwykle kontrowersyjnym tekście ${ }^{43}$, jest przyznanie państwu walczącemu ze zorganizowanym na wzór ISIS, Al-Kaidy czy Rebelii terrorem

38 Alderaan był planetą neutralną, jednakże więziona przez Tarkina przywódczyni rebeliantów Leia Organa wskazała go jako poszukiwaną przez niego bazę. Tarkin działał więc w pewnym stopniu na podstawie informacji uzyskanych od wysoko postawionego jeńca.

39 Wypada tu zauważyć, że w Nowej nadziei Darth Vader jest tylko jednym z dowódców sił specjalnych, dopiero w kolejnych częściach sagi występuje jako miecz i dłoń imperatora. Może to tłumaczyć jego postawę jako posłusznego wykonawcy rozkazów. Ta kwestia wymaga jednak dalszych badań.

40 Powrót Jedi

41 Struktura etniczna aktorów walczących o władzę w Gwiezdnych wojnach zasługuje na pogłębioną analizę. W tym miejscu należy jednak zauważyć, że w całej sadze najbardziej zróżnicowanymi grupami są: rycerze Jedi, co można tłumaczyć tym, że Moc wybierała swoje naczynia w sposób statystycznie sprawiedliwy, oraz separatyści hrabiego Dooku, co pokazuje, że jego bunt miał głębokie podłoże społeczne i był oparty na prawdziwej wspólnocie interesów rozmaitych ras.

42 Obi-Wan Kenobi w Nowej nadziei nie tyle ukrywa się przed siepaczami Dartha Vadera, ile stara się zapomnieć o niechlubnej roli Jedi w wydarzeniach z czasów Republiki. Podobnie Luke Skywalker w Ostatnim Jedi dostrzega bankructwo jediiskiego sposobu uprawiania polityki.

43 W.C. Bradford, Trahison des professeurs: The critical law of armed conflict academy as an Islamist fifth column, ,National Security Law Journal” 3, 2015, nr 2, s. 278 n. — artykuł ten doprowadził do zwolnienia autora z zatrudniającej go uczelni. Co do innych, mniej kontrowersyjnych ujęć wojny sprawiedliwej w kontekście wojny z terroryzmem zob. Intervention, Terrorism and Torture: Contemporary Challenges to Just War Theory, red. S.P. Lee, Dordrecht 2007, passim. 
prawa zwalczania go wszystkimi środkami, w tym takimi, które w oczywisty sposób łamią prawnomiędzynarodowe zasady prowadzenia wojny czy przyrodzone prawa ludzi i nieludzi. Niezależnie od tego, czy podzielamy ten pogląd ${ }^{44}$, wydaje się, że przed przyjęciem tezy o nieprawomocności władzy imperialnej jako łamiącej podstawowe prawa istoty myślącej i obywatela republiki należy zadać sobie jeszcze jedno pytanie: czy działania Imperatora nie mieściły się w ramach obowiązującego w Republice i Imperium porządku prawnego? Zauważmy bowiem, że przemoc Imperium (a wcześniej Republiki, separatystów Dooku i Federacji Handlowej) w Gwiezdnych wojnach nakierowana jest zawsze na określonego przeciwnika i nawet jeśli dotyka cywilów (poddanych władcy związanych z nim zależnością lenną lub umową społeczną), nie dotyka zasadniczo nikogo prócz stron konfliktu ${ }^{45}$.

$\mathrm{Z}$ pomocą przychodzi nam tu znów analiza prawnoporównawcza. To, co dzieje się w uniwersum Gwiezdnych wojen, wydaje się mieć swój odpowiednik w innym uniwersum, a mianowicie Diuny. Oba systemy są podobne w tym sensie, że mamy tu organizmy pangalaktyczne ze wspólną władzą centralną, luźno spajającą rządzące poszczególnymi światami rody Landsraatu oraz quasi-religijnymi zakonami Bene Gesserit, Bene Tleilax, Mentatów i Gildii Kosmicznej formalnie i nieformalnie uczestniczących w sprawowaniu władzy jako podmioty pozbawione legitymacji demokratycznej, a zorganizowane w sposób zbliżony do Jedi. Nieuchronne konflikty polityczne i militarne są w tym uniwersum kanalizowane tak, by dotyczyły tylko stron bezpośrednio zainteresowanych, a nie dotykały pozostałych. Upadłe rody udają się na wygnanie do „więziennego” sektora Tupile albo — jak Wayku — uzyskują status personelu pokładowego liniowców Gildii bez prawa zejścia z pokładu. Rody, które użyją broni atomowej, są fizycznie eliminowane przez imperialnych sardaukarów (siły specjalne) itp. Istnieją także specyficzne formy wojny zmierzające do fizycznej i ostatecznej eliminacji przeciwnika. Takimi działaniami była wojna asasynów, ograniczona co do sposobu i metod prowadzenia oraz wymagająca formalnego wypowiedzenia, a także kanly - rodzaj vendetty kończącej się fizyczną eliminacją wszystkich członków rodu przeciwnika. Podobny charakter miało wyjęcie spod prawa przez imperatora - los, który spotkał powieściową rodzinę Verniusów.

Analiza zdarzeń zachodzących w Gwiezdnych wojnach od części III do VI prowadzi do wniosku, że mamy do czynienia z waśnią między zwolennikami starego porządku a legalną władzą imperialną, zbliżoną do kanly. To brutalne rozwiązanie zapewnia jednak spokój w galaktyce i minimalizuje straty. Wydaje się,

44 Piszący te słowa uważa przedstawione stanowisko za ekstremalne i uważa, że nawet w sytuacjach skrajnych jedyną różnicą między terrorystami a demokratycznym państwem może być stosunek do pokonanego przeciwnika.

45 Wyjątkiem jest wspomniane wcześniej zniszczenie Alderaana jako rzekomej bazy rebeliantów i sposób traktowania Ewoków, spowodowany jednak raczej uprzedzeniami rasowymi, a nie taktyką wojenną. 
że za hipotezą kanly przemawiają także dwa fakty niebudzące wątpliwości — po pierwsze, taki charakter miała waśń Jedi z Sithami: Palpatine i jego uczeń ${ }^{46}$ są dwoma ostatnimi przedstawicielami swojego zakonu, reszta najwyraźniej została wybita do nogi przez Jedi. Ich wybór sprowadza się więc do prostego „my albo oni". Po drugie, znamienne w tym kontekście jest zachowanie Luke'a Skywalkera, który gdy dostrzega, że jego siostrzeniec Kylo Ren skłania się ku heretyckiemu odłamowi religii (czyli „ciemnej” stronie Mocy), a co za tym idzie - staje się objętym zawładniętym vendettą Sithem, chce go zabić. Potem żałuje, nie że chciał zabić swojego siostrzeńca, ale że się zawahał, a co gorsza - że się wyda$\nmid \mathrm{o}^{47}$. Doszczętne („,co do częda” — do ostatniego dziecka) tępienie przeciwników musiało być zatem mocno zakorzenione w kulturze republikańskiej.

\section{Wnioski}

Jak widać z zamieszczonej w artykule analizy, przyjmowanie stereotypowego czarno-białego obrazu Imperium i Rebelii jest nadmiernym uproszczeniem. Analizowane zmiany ustrojowe nie miały charakteru nadzwyczajnego, mieściły się w ramach ustalonego galaktycznego porządku prawnego. Mieszały się tu jednak elementy charakterystyczne dla ustrojów współczesnych, jak szacunek dla zgodnego z procedurą przejęcia władzy, z feudalnymi, jak zemsty rodowe, utrzymywanie niewolnictwa czy nierównoprawne traktowanie ,ras niższych”. Do ustroju uniwersum Gwiezdnych wojen nie można jednak przykładać naszej miary, gdyż budowany był w innych realiach społeczno-politycznych. Nie ma tu więc wbrew intuicji — dobrych, republikańskich rebeliantów i złego Imperatora. Są tylko uczestnicy walki o przywrócenie starego porządku i modernizatorzy, dający Republice nowy, bardziej efektywny, choć nie bardziej moralny sznyt. Również ciąg dalszy sagi nie sugeruje, jakoby restauracja Republiki była zmianą na lepsze. Wszak Imperium było w stanie podjąć ogromny wysiłek finansowy i technologiczny budowy w kilkuletnim odstępie czasu dwóch Gwiazd Śmierci. Na skutek zniszczenia stacji wysiłek ten stał się nieopłacalny, gdyż — jak twierdzi Zachary Feinstein $^{48}$ — spłata długu zaciągniętego na budowę stacji gwarantowała kryzys gospodarczy. Po zwycięstwie odradzająca się Republika znalazła się więc w stanie zapaści porównywalnej z Wielkim Kryzysem lat trzydziestych XX wieku9,

46 Jedynie na marginesie należy dodać, że szanse Sitha-ucznia na osiągnięcie statusu mistrza były niewielkie ze względu na dużą śmiertelność w populacji.

47 Ostatni Jedi.

48 Z. Feinstein, It's a trap: Emperor Palpatine's poison pill, https://arxiv.org/pdf/1511.09054v1. pdf (dostęp: 24.12.2018).

49 Z. Feinstein, In 'Star Wars, 'was the Death Star too big to fail?, „New York Times Sunday Review" 1.01.2016, https://www.nytimes.com/2016/01/03/opinion/in-star-wars-was-the-death-star-too-big-to-fail.html (dostęp: 24.12.2018). 
natomiastnowe władze republikańskie wyraźnie nie uczyły sięna swoich błędachw galaktyce epoki restauracji obywatele żyją w postapokaliptycznych, by nie rzec dosadniej, warunkach, natomiast jedynym miejscem tętniącym życiem jest stolica. Świadomość, że republikańskie elity zamiast odbudowywać gospodarkę, zadbały, by żyło im się lepiej, choćby kosztem obywateli, osłabia nieco współczucie dla ofiar bazy Starkiller ${ }^{50}$.

Przytoczona analiza pokazuje także, że niezależnie od swego okrucieństwa i lekceważenia podstawowych praw ludzi i nieludzi galaktyczny system rządów wykazuje się stabilnością. Elitę republikańską w momencie jej największego rozkładu zastąpiło Imperium. Upadło ono jednak, gdy jego władca zaczął przedkładać niezdrowe uczucie względem Luke'a Skywalkera nad dobro państwa; zastąpiła je na chwilę odradzająca się Republika, której ponowne i niezbyt udolne rządy zakończyło nadejście Najwyższego Porządku wykazującego się znacznie lepszym zrozumieniem rzeczywistości gospodarczej, jako że zaprojektowana przezeń następczyni Gwiazdy Śmierci - baza Starkiller, o lepszej niż Gwiazda Śmierci efektywności (umożliwiała atak na znaczne dystanse, podczas gdy Gwiazda wymagała umieszczenia na orbicie niszczonej planety) - pochłonęła zaledwie nieco ponad $4 \%$ kosztów pierwowzoru ${ }^{51}$. Z wydarzeń pokazanych w Ostatnim Jedi wynika też, że Najwyższy Porządek jest również odporny na rewolucje pałacowe, które nie zaburzają funkcjonowania państwa. Można zatem przyjąć, że w uniwersum Gwiezdnych wojen ustrój optymalny to taki, który zapewnia ciągłość sprawowania władzy i pozwala państwu przetrwać, nawet jeśli rządzone jest przez koterie, krwiożerczych psychopatów czy dorosłych o mentalności dwunastolatka. Ceną, jaką się płaci za to optimum, jest dobrostan obywateli tudzież rezygnacja z ochrony podstawowych wartości. Co z kolei prowadzi nas do pytania: czy jest taka cena, której za przetrwanie państwa nie warto zapłacić?

\section{Bibliografia}

Allan J. et al., Stars \& Empire: 10 Galactic Tales (Stars \& Empire Box Set Collection), Limited Kindle Edition [b.d.w.].

Arendt H., Korzenie totalitaryzmu, t. 2, przeł. D. Grinberg, M. Szawiel, Warszawa 2008.

Asimov I., Fundacja, przeł. A. Jankowski, Poznań 1987.

Bradford W.C., Trahison des professeurs: The critical law of Armed Conflict Academy as an Islamist fifth column, „National Security Law Journal” 3, 2015, nr 2.

50 Jedynie na marginesie należy zauważyć, że przyzwoity poziom życia zapewnia swoim obywatelom Najwyższy Porządek oraz miasto handlarzy bronią. Konstatacja ta może stanowić punkt wyjścia do badań nad wpływem formy rządów na rozwój gospodarczy pangalaktycznych podmiotów prawa kosmicznego.

51 Z. Feinstein, Starkiller base: A Star Wars (economic) story, „Fictionomics”, https://sites. wustl.edu/fictionomics/2017/11/29/starkiller-base-cost/ (dostęp: 22.02.2018). 
Feinstein Z., In 'Star Wars, 'was the Death Star too big to fail?, „New York Times Sunday Review” 1.01.2016, https://www.nytimes.com/2016/01/03/opinion/in-star-wars-was-the-death-star-too-big-to-fail.html.

Feinstein Z., It's a trap: Emperor Palpatine's poison pill, https://arxiv.org/pdf/1511.09054v1.pdf.

Feinstein Z., Starkiller base: A Star Wars (economic) story, „Fictionomics”, https://sites.wustl.edu/ fictionomics/2017/11/29/starkiller-base-cost/.

Fiedler S., The right to rebel: Social movements and civil disobedience, „Cosmopolitan Civil Societies Journal” 1, 2009, nr 2, https://epress.lib.uts.edu.au/journals/index.php/mcs/article/viewFile/1205/1309.

Gonzales G.A., The Politics of Star Trek: Justice, War and the Future, Dordrecht 2015.

The Greenwood Encyclopedia of Science Fiction and Fantasy Themes, Works and Wonders, t. 2, red. G. Westfahl, Westport-London 2005.

Herbert B., Anderson K., Ród Atrydów, przeł. M. Michowski, Warszawa 2012.

Herbert F., Diuna, przeł. M. Marszał, Warszawa 1985.

Intervention, Terrorism and Torture: Contemporary Challenges to Just War Theory, red. S.P. Lee, Dordrecht 2007.

Lovecraft H.P., Zgroza w Dunwich i inne przerażające opowieści, przeł. M. Płaza, Warszawa 2012.

Schmitt C., Dyktatura. Od źródet nowożytnej idei suwerenności do proletariackiej walki klas, przeł. K. Wudarska, Białystok 2016.

Turing A., Computer machinery and intelligence, „Mind. New Series” 59, 1950, nr 236, https:// academic.oup.com/mind/article/LIX/236/433/986238.

Varol O.O., Democratic Coup d'Etat, „Harvard International Law Journal” 53, 2012, nr 2.

\section{Filmografia}

Gwiezdne wojny. Część 1: Mroczne widmo, scen. i reż. G. Lucas, USA 1999.

Gwiezdne wojny. Część 2: Atak klonów, scen. G. Lucas, J. Hales, reż. G. Lucas, USA 2002.

Gwiezdne wojny. Czesść 3: Zemsta Sithów, scen. i reż. G. Lucas, USA 2005.

Gwiezdne wojny. Część 4: Nowa nadzieja, scen. i reż. G. Lucas, USA 1977.

Gwiezdne wojny. Część 5: Imperium kontratakuje, scen. L Kasdan, G. Brackett, G. Lucas, reż. I. Kershner, USA 1980.

Gwiezdne wojny. Część 6: Powrót Jedi, scen. L. Kasdan, G. Lucas, reż. R. Marquand, USA 1983.

Gwiezdne wojny. Część 7: Przebudzenie mocy, scen. L. Kasdan, J.J. Abrams, M. Arndt, reż. J.J. Abrams, USA 2015.

Gwiezdne wojny. Część 8: Ostatni Jedi, scen. i reż. R. Johnson, USA 2017.

Star Trek: Discovery, sezon 1. The Vulcan Hello, scen. B. Fuller, A. Goldsman, reż. D. Semel, USA 2017.

Star Trek: Enterprise, sezon 4. In a Mirror, Darkly, cz. 1, scen. M Sussman, reż. J.L. Conway, USA 2005.

Star Trek: Enterprise, sezon 4. In a Mirror, Darkly, cz. 2, scen. M. Sussman, M. Cotto, reż. M.V. Rush, USA 2005.

Star Trek: The Original Series, sezon 2, Mirror, Mirror, scen. J. Bixby, reż. M. Daniels, USA 1967.

Star Trek: Rebelia, scen. R. Breman, M. Piller, reż. J. Frakes, USA 1998. 


\section{BETWEEN TWO SIDES OF POWER: A CONTRIBUTION TO CONSTITUTIONAL ANALYSIS OF SCIENCE-FICTION UNIVERSA}

\section{Summary}

In popular parlance the Star Wars universe often serves as an example of a binary division between good Rebels and evil Empire. However, a detailed legal analysis of the turbulent political and legal history of the good old Republic and its transformation into the Empire casts doubts on this popular opinion.

The Republic seems to be a degenerate system, based on exploitation of the weak, slavery and dominance of the military order (the Jedi), exercising power without any democratic control. Surprisingly, the transformation of the Republic into the Empire was formally admissible, and backed up by republican constitutional principles. Moreover, it has been purported here that the political system of the galaxy had very strong feudal relics and allowed both for vendettas and the right to rebel against the goverment. The Rebellion was in fact a counterrevolutionary movement whose main goal was to re-establish the ancient regime and anihilate the last two representatives of the schismatic Jedi sect (the Siths), while the Empire was trying to establish a ruthless, but effective system of government. Thus, what we have here is not a battle of Good against Evil but simply a civil war between conservative terrorists and authoritarian reformers. Surprisingly, a short-lived victory of the Rebellion leads to a social and economic crisis, while the restoration of the Empire by the New Order guarantees stability of the economic and political system. Moreover, imperial feuds and vendettas impact only the major players, while the commoners are not directly affected.

Keywords: Star Wars, law and literature, right to rebel.

Piotr Stec

pstec@uni.opole.pl 